\title{
Phosphorus Application Decreased Copper Concentration but Not Iron in Maize Grain
}

\author{
Wei Zhang ${ }^{1,2}{ }^{-}$, Chunqin Zou ${ }^{2}\left(\mathbb{0}\right.$, Xiuxiu Chen ${ }^{2}$, Yumin Liu ${ }^{2}$, Dunyi Liu ${ }^{1,3}$, Huaiyu Yang 1,3(1), \\ Yan Deng ${ }^{1,3}$ and Xinping Chen ${ }^{1,3,4, *}$ \\ 1 College of Resources and Environment, Academy of Agricultural Sciences, Southwest University, \\ Chongqing 400716, China; zw0730@swu.edu.cn (W.Z.); liudy1989@swu.edu.cn (D.L.); \\ yanghuaiyu@swu.edu.cn (H.Y.); dyan0907@swu.edu.cn (Y.D.) \\ 2 College of Resources and Environment, Key Laboratory of Plant-Soil Interactions, Ministry of Education, \\ China Agricultural University, Beijing 100193, China; zcq0206@cau.edu.cn (C.Z.); \\ 13164613503@163.com (X.C.); liuyumin666@126.com (Y.L.) \\ 3 Chongqing Key Laboratory of Efficient Utilization of Soil and Fertilizer Resources, Southwest University, \\ Chongqing 400716, China \\ 4 Interdisciplinary Research Center for Agriculture Green Development in Yangtze River Basin, Southwest \\ University, Chongqing 400716, China \\ * Correspondence: chenxp2017@swu.edu.cn; Tel.: +86-023-68251082
}

Received: 28 September 2020; Accepted: 3 November 2020; Published: 5 November 2020

\begin{abstract}
Copper $(\mathrm{Cu})$ and iron $(\mathrm{Fe})$ are essential micronutrients for plants and animals. How phosphorus $(\mathrm{P})$ application affects $\mathrm{Cu}$ and Fe concentrations in maize grain still remains unclear. Two-year field studies were conducted in a long-term experiment with six P levels $(0,12.5$, $25,50,100$, and $200 \mathrm{~kg} \cdot \mathrm{ha}^{-1} \mathrm{P}$ ) on calcareous soil. Phosphorus application significantly decreased the average grain $\mathrm{Cu}$ concentration by $12.6 \%$ compared to no $\mathrm{P}$ treatment, but had no effect on grain Fe concentration. The copper content increased as the $\mathrm{P}$ application rate increased from 0 to 25 or $50 \mathrm{~kg} \cdot \mathrm{ha}^{-1}$, but then decreased, while Fe content kept increasing. As the P application rate increased, the specific $\mathrm{Cu}$ uptake by the roots decreased, but not for Fe. The root length density in response to $\mathrm{P}$ application had a positive relationship with shoot $\mathrm{Cu}$ and $\mathrm{Fe}$ content. The shoot $\mathrm{Cu}$ content and grain $\mathrm{Cu}$ concentration decreased with the reduction in the arbuscular mycorrhizal fungi (AMF) colonization of roots due to increasing $\mathrm{P}$ application. The reduction in grain $\mathrm{Cu}$ concentration with increasing $\mathrm{P}$ rates could be partly explained by the decreasing uptake efficiency.
\end{abstract}

Keywords: grain; $\mathrm{Cu}$; Fe; phosphorus; AMF colonization

\section{Introduction}

Maize is an important ingredient in animal feed and industrial products [1], providing not only substantial levels of calories and protein [2], but also micronutrients such as copper $(\mathrm{Cu})$, iron $(\mathrm{Fe})$, and zinc $(\mathrm{Zn})[3,4]$. The improper management of maize crops, however, results in low contents of micronutrients in grain, such that the grain nutrients in the feed do not meet animal requirements [5]. As a result, exogenous micronutrients must be added to the feed to increase animal body weight [6]. The addition of large amounts of micronutrients, and especially $\mathrm{Cu}$, to the feed can result in substantial soil and water pollution $[7,8]$. It is therefore important to increase the micronutrients supplied to animals by increasing the micronutrient contents in the grain rather, than using chemical additives directly in the feed.

The application of phosphorus $(\mathrm{P})$ fertilizer in intensive agriculture production is a crucial measure for increasing grain yield $[9,10]$, but it may affect the micronutrient contents in grain. The antagonistic effects between P-Zn and P-Cu have long been observed before now [11,12]. Whereas these 
studies mostly reported on how $\mathrm{P}$ application affected the $\mathrm{Cu}$ and $\mathrm{Zn}$ nutrients in the seeding stage through pot experiments, less attention was focused on grain. With regard to grain micronutrients, the mobilization from root to grain, including the uptake by roots and translocation within plants, are of great importance. Recently, long-term field experiments indicated that the application of $\mathrm{P}$ fertilizer significantly decreased grain Zn concentration in maize [13] and wheat [14], and the inhibition mainly occurred in the uptake by root, but not in the translocation process. It is still not clear, however, to what extent $\mathrm{P}$ application affects grain $\mathrm{Cu}$ nutrition, and the influence of $\mathrm{P}$ application on $\mathrm{Cu}$ transportation from root to grain should be receiving much more attention. Quantitative study is required in the field to analyze whether $\mathrm{P}$ fertilizer application influences $\mathrm{Cu}$ uptake efficiency by roots, or the translocation to grain.

Efficient uptake by the roots is the key to acquiring soil nutrients, and root growth (especially root morphology) is thought to significantly affect the root uptake of mineral elements [15,16]. Although the uptake of mineral elements can also increase as root quantity increases [17,18], a high concentration of $\mathrm{P}$ in the shoots may reduce the total and specific root length (the ratio of root length to root dry mass) of maize [19]. Teng et al. [20] showed that, under field conditions, the root dry weight and root length density (length of roots/unit volume of soil) increased as the $\mathrm{P}$ application rate increased up to a critical level, but did not increase further once the rate exceeded that critical level. However, whether the changes in maize root morphology caused by $\mathrm{P}$ application influence $\mathrm{Cu}$ uptake has not been reported. Maize is easily colonized by arbuscular mycorrhizal fungi (AMF) [21], and under P-deficient conditions, the AMF colonization of roots enhances P uptake [22,23]. AMF colonization can also increase the uptake of some micronutrients, especially $\mathrm{Cu}$ [24]. Lambert et al. [25] found that the $\mathrm{Cu}$ concentration in maize shoots was significantly greater in mycorrhizal than in non-mycorrhizal plants. Subsequent research confirmed that the total $\mathrm{Cu}$ content in shoots was higher in mycorrhizal than in non-mycorrhizal plants [26,27]. Deng et al. [28] found that the AMF colonization of field maize plants was severely inhibited when the soil P level was above the agronomic critical level. Under field conditions, however, it remains unclear whether excessive $\mathrm{P}$ application reduces the AMF colonization of maize roots, and thereby decreases $\mathrm{Cu}$ uptake in roots and shoots.

In addition, the effect of $\mathrm{P}$ application on the concentration of Fe in maize grain is less understood. It is clear that under Fe-deficient conditions, maize secretes mugineic acid family phytosiderophores through the phytosiderophore efflux transporter, and takes up Fe in the form of Fe(III)-phytosiderophore complexes [29-31]. The secreted amount of phytosiderophore is not only related to nutrient status, such as deficiencies of $\mathrm{Fe}, \mathrm{Mn}, \mathrm{Cu}$ and $\mathrm{Zn}$ in soil and hydroponic growth conditions [32], but also to root traits. A study from Ptashnyk et al. [33] indicated that root density has a large effect on Zn uptake per unit of phytosiderophore secreted. It is unclear if the changes in maize root morphology caused by $\mathrm{P}$ application influence Fe uptake, and if $\mathrm{P}$ fertilizer application affects Fe translocation to grain.

Our previous studies have focused on $\mathrm{P}$ reducing grain $\mathrm{Zn}$ and the possible mechanisms in maize [13]. As such, the aims of the current study are continually (1) to quantitatively determine how the $\mathrm{P}$ application rates affect grain $\mathrm{Cu}$ and Fe concentrations, (2) to ascertain the $\mathrm{Cu}$ and Fe uptake and translocation processes from root to grain as correlated to varied P rates, and (3) to elucidate the roles of root morphology and AMF colonization in $\mathrm{Cu}$ and Fe uptake under varying P rates.

\section{Materials and Methods}

\subsection{Field Experiment}

A field experiment with summer maize (Zea mays L.) was conducted from June to October in 2014 and 2015 at the Quzhou experiment station, Hebei Province, on the North China Plain. The soil of the experiment site is a typical calcareous alluvial soil and the initial $\mathrm{pH}$ was 8.0 (1:2.5 $w / v$ in water). Before maize was sown and fertilizer was applied in 2014, the soil bicarbonate-extractable (Olsen method) P concentration [34] was $6.0 \mathrm{mg} \cdot \mathrm{kg}^{-1}$, and the average soil diethylene triamine pentacetic acid (DTPA)-extractable $\mathrm{Cu}$ and Fe concentrations [35] were 0.90 and $7.78 \mathrm{mg} \cdot \mathrm{kg}^{-1}$, respectively. 
The field experiment included six P application levels: 0, 12.5, 25, 50, 100, and $200 \mathrm{~kg}$ of $\mathrm{P} \mathrm{ha}{ }^{-1}$. Each treatment had four replicate plots, and the area of each plot was $75 \mathrm{~m}^{2}(10 \mathrm{~m} \times 7.5 \mathrm{~m})$. The cultivar of summer maize was "Zhengdan 958", and the planting density was 67,000 plants ha ${ }^{-1}$ in 2014 and 75,000 plants ha ${ }^{-1}$ in 2015. In each year, $75 \mathrm{~kg}$ of nitrogen $(\mathrm{N}) \mathrm{ha}^{-1}$ as urea $(46 \% \mathrm{~N}), 60 \mathrm{~kg}^{\circ} \mathrm{K}_{2} \mathrm{O}$ $\mathrm{ha}^{-1}$ as potassium (K) sulfate, and $\mathrm{P}$ fertilizer at the indicated rates as calcium superphosphate were broadcast before sowing. At the 6-leaf stage (V6), another $150 \mathrm{~kg}$ of $\mathrm{N} \mathrm{ha}^{-1}$ was topdressed. The plots were irrigated only one time, i.e., at the V6 stage. A pre-emergence herbicide was applied to control weeds, and Omethoate (Planck Biochemical Industry, Zhengzhou, China) was applied when the plants were at the 12-leaf (V12) stage to control aphids.

\subsection{Plant and Soil Sampling}

At the physiological maturity stage (R6), to evaluate the maize grain yield, the ears from a $7.2 \mathrm{~m}^{2}$ $(3 \mathrm{~m} \times 2.4 \mathrm{~m})$ area in the center of each plot were harvested (the grain yield was expressed on a $15.5 \%$ moisture basis). Meanwhile, shoot samples for nutrient analysis (4 plants per plot) were collected and separated into grain and straw. At the tasseling (VT) stage in 2014, the root dry weight, root length and AMF colonization were determined for roots collected from one $0.18 \mathrm{~m}^{3}$ block of soil from each plot. Each soil block was $120 \mathrm{~cm}$ long, $25 \mathrm{~cm}$ wide, and $60 \mathrm{~cm}$ deep. The block was located between two plants in adjacent rows (the row spacing was $60 \mathrm{~cm}$ ). All roots in each block were collected by washing the soil over sieves. The roots from the $0-20 \mathrm{~cm}$ section of topsoil were used to measure AMF colonization, and all roots were assessed by root dry weight and root length. The root dry weight $\left(\mathrm{g} \mathrm{m}^{-2}\right)$ used in this text meant total weight from the $60 \mathrm{~cm}$ soil layer. The root length density meant the root density per unit volume $\left(\mathrm{cm}^{3}\right)$. At the maturity stage of maize, six subsamples of soil in each plot were taken from a 0-20 cm soil depth with a stainless steel auger then composited into a single sample.

\subsection{Plant and Soil Analyses}

All plant samples included roots and shoots that were sampled from the same plant at tasseling, and the grains and straws that were taken from the same plant at the maturity stage were firstly washed with tap water and then with deionized water before they were dried at $60-65^{\circ} \mathrm{C}$ to a constant weight. A microwave-accelerated reaction system (CEM, Matthews, NC, USA) was used to digest the plant samples with $\mathrm{HNO}_{3}-\mathrm{H}_{2} \mathrm{O}_{2}$. The copper and Fe concentrations in the digested solutions were determined by inductively coupled plasma optical emission spectroscopy (ICP-OES, OPTIMA 3300 DV, PerkinElmer Inc, Boston, MA, USA). To verify the digestion procedures and to calibrate the ICP-OES, the IPE684 grain and IPE126 straw samples (Wageningen University, Wageningen, The Netherlands) were used as the reference materials. The Olsen-P concentrations of soil from $0-20 \mathrm{~cm}$ were measured by the molybdovanadate phosphate method [34] with a colorimeter (Macy UV-1700, Macy Instrument Industry, Shanghai, China) after being extracted with $0.5 \mathrm{M} \mathrm{NaHCO}_{3}$ at $\mathrm{pH} 8.5$ $\left(180 \mathrm{rpm}, 25^{\circ} \mathrm{C}\right)$. The DTPA-Fe and $\mathrm{Cu}$ concentrations of soil were measured by ICP-OES (Agilent 5110, Agilent Technologies Co. Ltd., Palo Alto, CA, USA) after being extracted with $0.005 \mathrm{~mol} \mathrm{~L}^{-1}$ DTPA.

To measure root length, all root samples from the $0-60 \mathrm{~cm}$ soil layer were washed with tap water and kept at $-20{ }^{\circ} \mathrm{C}$ before images were captured with an optical scanner (Epson V850Pro, Seiko Epson Corporation, Nagano-ken, Japan); then the images were analyzed with WinRHIZO software (Quebec, QC, Canada) to calculate the total root length. For the determination of AMF colonization, the root samples $(0.5 \mathrm{~g}$ per plot) were cut into $1 \mathrm{~cm}$ segments, and the segments were placed in $10 \%$ $(w / v) \mathrm{KOH}$ at $90{ }^{\circ} \mathrm{C}$ in a water bath for $1 \mathrm{~h}$. The root samples were then placed in $2 \% \mathrm{HCl}$ for 5 min and stained with trypan blue. For each sample, 15 root segments were evaluated for AMF colonization on a scale from $0 \%$ (no sign of infection) to 100\% (heavily infected) [23].

\subsection{Statistical Analysis}

For each year, one-way analyses of variance (ANOVAs) were used to test the effects of the $P$ application rate on the dependent variables. When the ANOVAs were significant, the means were 
compared with an LSD test at $p<0.05$. SAS software (SAS 8.0, SAS Institute Inc., Cary, NC, USA) was used for statistical analysis. Relationships between shoot $\mathrm{Cu}$ content, shoot Fe content and root length density, and relationships between shoot $\mathrm{Cu}$ content, grain $\mathrm{Cu}$ concentration and AMF colonization of root were quantified by regression models.

In this report, nutrient 'content' is equal to nutrient concentration multiplied by biomass. 'Shoot' indicated the above-ground part of the maize plant. Specific $\mathrm{Cu}$ uptake was calculated from shoot $\mathrm{Cu}$ content divided by root length, and specific Fe uptake was calculated in the same way.

\section{Results}

\subsection{Cu and Fe Concentrations in Grain and Straw as Affected by P Fertilization}

In both years, the grain $\mathrm{Cu}$ concentration was reduced significantly with the increase in $\mathrm{P}$ applications (Figure 1a). In 2014, compared to P0, the grain $\mathrm{Cu}$ concentration decreased by $3.1 \%, 7.4 \%, 12.0 \%, 16.4 \%$ and $25.6 \%$ in P12.5, P25, P50, P100 and P200, respectively. In 2015, the grain Cu concentration continually reduced from $1.78 \mathrm{mg} \cdot \mathrm{kg}^{-1}$ with P0 to $1.40 \mathrm{mg} \cdot \mathrm{kg}^{-1}$ with P200. Phosphorus application also significantly reduced the straw $\mathrm{Cu}$ concentration (Figure 1c). Varying the $\mathrm{P}$ treatment had no effect on the Fe concentration in grain and straw in both years, and the grain Fe concentration almost stayed within a certain range from 18.8 to $21.2 \mathrm{mg} \cdot \mathrm{kg}^{-1}$ (Figure $1 \mathrm{~b}, \mathrm{~d}$ ).
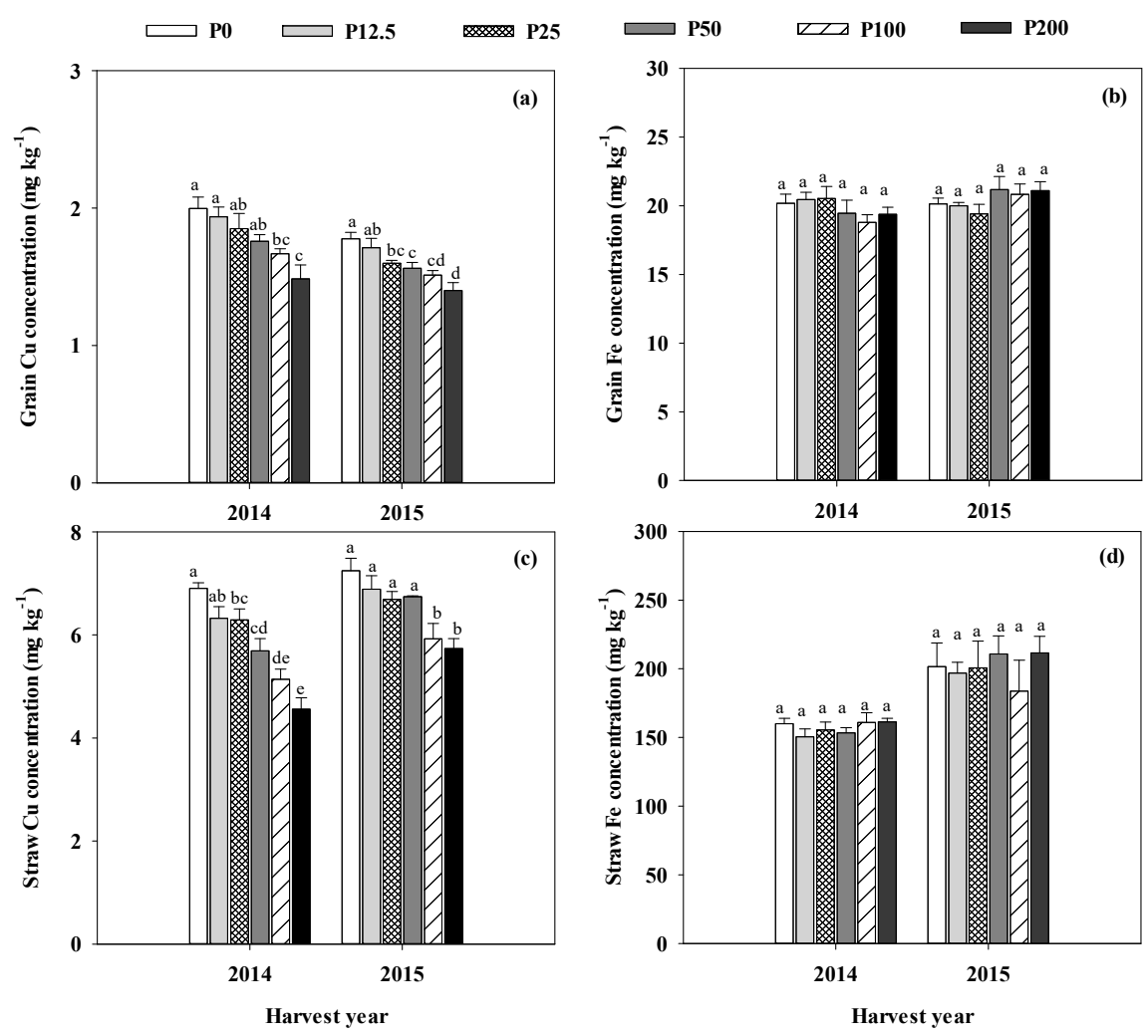

Figure 1. Cu concentration in grain (a) and straw (c), Fe concentration in grain (b) and straw (d), in 2014 and 2015 of maize as affected by P application rate. P0, P12.5, P25, P50, P100, and P200 equal 0, 12.5, 25, 50,100 , and $200 \mathrm{~kg} \cdot \mathrm{ha}^{-1} \mathrm{P}$ applied, respectively. Values are means $+\mathrm{SE}$ of four replications. Within each year, means with the same letters indicate no significant difference according to an LSD test $(p<0.05)$.

\subsection{Cu and Fe Content, Ratio of Grain to Shoot $\mathrm{Cu}$ and Fe Content as Affected by P Fertilization}

The copper content $\left(\mathrm{g} \cdot \mathrm{ha} \mathrm{a}^{-1}\right)$ in the grain and straw increased as the P application rate increased from 0 to $25 \mathrm{~kg} \cdot \mathrm{ha}^{-1}$, but then decreased at higher rates in 2014 (Figure 2a). In 2015, a similar trend was evident, in which the $\mathrm{Cu}$ content in grain and straw also increased first and then decreased 
with increasing $\mathrm{P}$ application, and it was highest at the $50 \mathrm{~kg} \cdot \mathrm{ha}^{-1} \mathrm{P}$ level (Figure 2a). Phosphorus application increased the contents of Fe in grain and straw in both cropping seasons (Figure 2b). The ratio of grain to shoot $\mathrm{Cu}$ content was less affected by $\mathrm{P}$ application in both cropping seasons, and averaged $26 \%$ and $25 \%$ in the first and second cropping season, respectively (Figure 2c). Phosphorus application also had little effect on the ratio of grain to shoot Fe content in the two cropping seasons, while a significant difference was only found between the P12.5, P50 and P100 treatments in 2014 (Figure 2d).
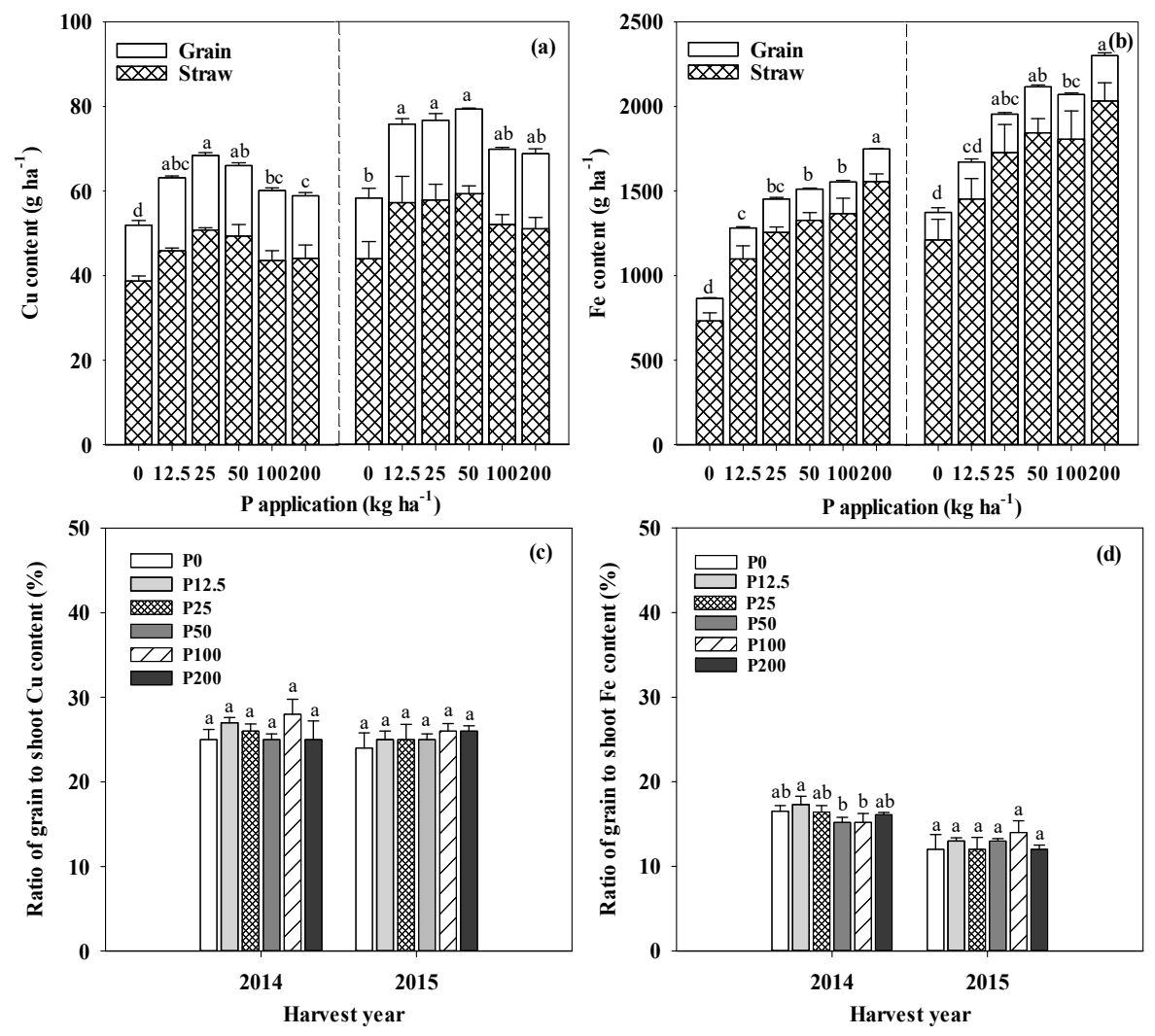

Figure 2. Content of $\mathrm{Cu}(\mathbf{a})$ and $\mathrm{Fe}(\mathbf{b})$ in grain and straw at maturity in 2014 and 2015, and ratio of grain to shoot $\mathrm{Cu}$ content (c) and Fe content (d) at maturity as affected by P application rate. P0, P12.5, P25, P50, P100, and P200 equal 0, 12.5, 25, 50, 100, and $200 \mathrm{~kg} \cdot \mathrm{ha}^{-1} \mathrm{P}$ applied, respectively. Values are means + SE of four replications. Within each year, means with the same letters indicate no significant difference according to an LSD test $(p<0.05)$.

\subsection{Root Morphology, Specific Cu and Fe Uptake as Affected by P Fertilization}

A significant increase in root dry weight was recorded between P0 and P25. (Figure 3a). Root length density ( $\mathrm{cm}$ of root per $\mathrm{cm}^{3}$ of soil) had an increasing tendency as the $\mathrm{P}$ application rate increased from 0 to $25 \mathrm{~kg} \cdot \mathrm{ha}^{-1}$, while no difference was found between P25, P50, P100 and P200 (Figure 3b). Phosphorus application reduced the specific $\mathrm{Cu}$ uptake (Figure 3c), but did not affect the specific Fe uptake (Figure 3d).

\subsection{Shoot $\mathrm{Cu}$ and Fe Content, Grain $\mathrm{Cu}$ and Fe Concentration Related to Root Length Density and AMF Colonization}

Figure 4 shows that a positive relationship was found between root length density and shoot $\mathrm{Cu}$ and Fe content. Although a regression relationship could be found between grain $\mathrm{Cu}$ concentration and root length density (Figure 4c), it was not appropriate to present the relationship, because it was illogical that the root length density had a negative effect on grain $\mathrm{Cu}$ concentration. As a result, the linear relationship was not shown. The arbuscular mycorrhizal fungi colonization of roots was positively 
related to the shoot $\mathrm{Cu}$ content and grain $\mathrm{Cu}$ concentration (Figure $5 \mathrm{a}, \mathrm{c}$ ), but was independent of shoot Fe content and grain Fe concentration (Figure $5 b, d$ ). It is also illogical to show the relationship between the shoot Fe content and AM colonization within the regression model (Figure 5b).
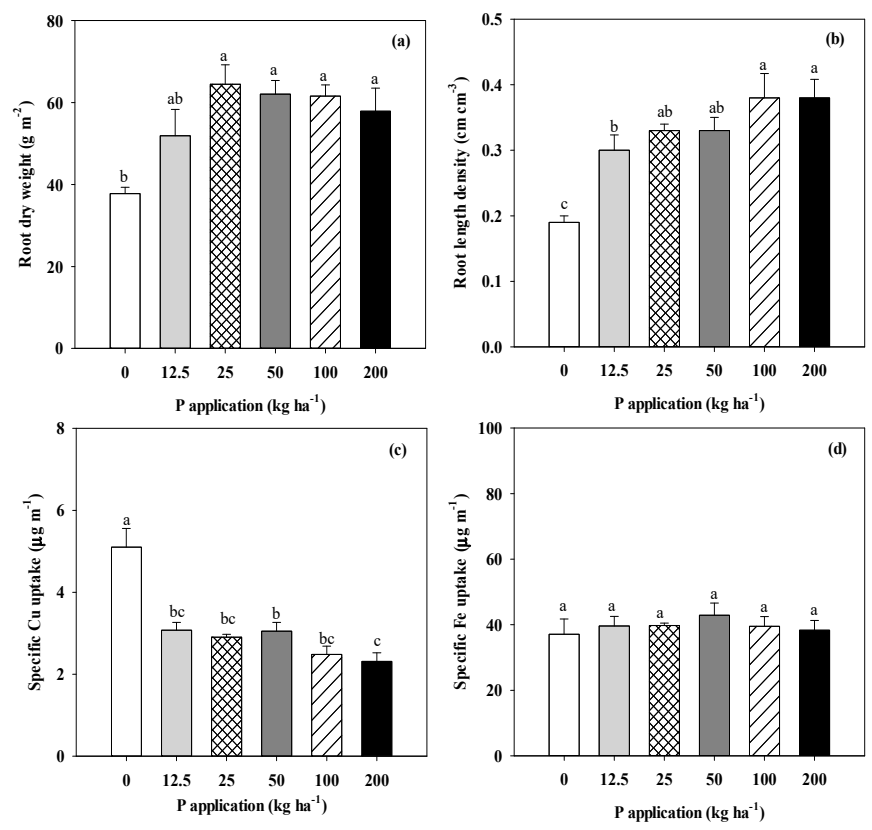

Figure 3. Root dry weight (a), root length density (b), specific $\mathrm{Cu}$ uptake (c), and specific Fe uptake (d) at tasseling as affected by P application rate in 2014 (these data were not collected in 2015). Values are means $+\mathrm{SE}$ of four replications. Within each panel, means followed by the same letters indicate no significant difference according to an LSD test $(p<0.05)$.
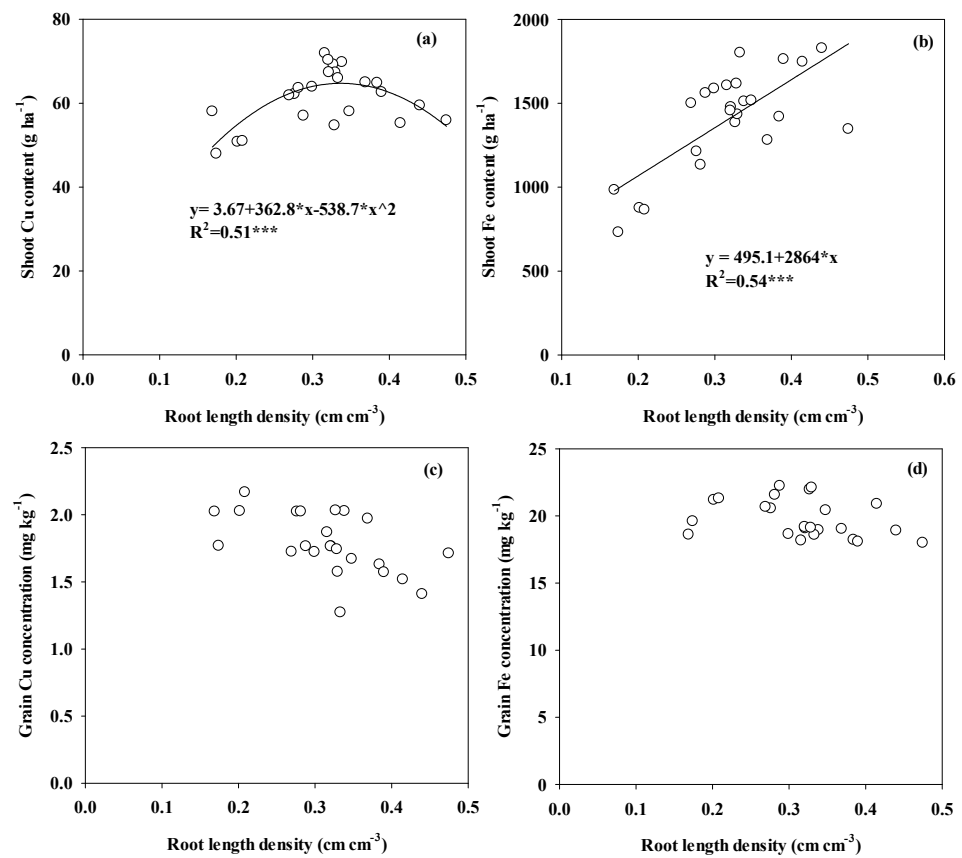

Figure 4. Relationship between root length density and shoot $\mathrm{Cu}$ content (a), shoot Fe content (b), grain $\mathrm{Cu}$ concentration (c) and grain Fe concentration (d) at tasseling in 2014 (these data were not collected in 2015). ${ }^{* * *}$ indicates that the regression is significant at $p<0.001$. 

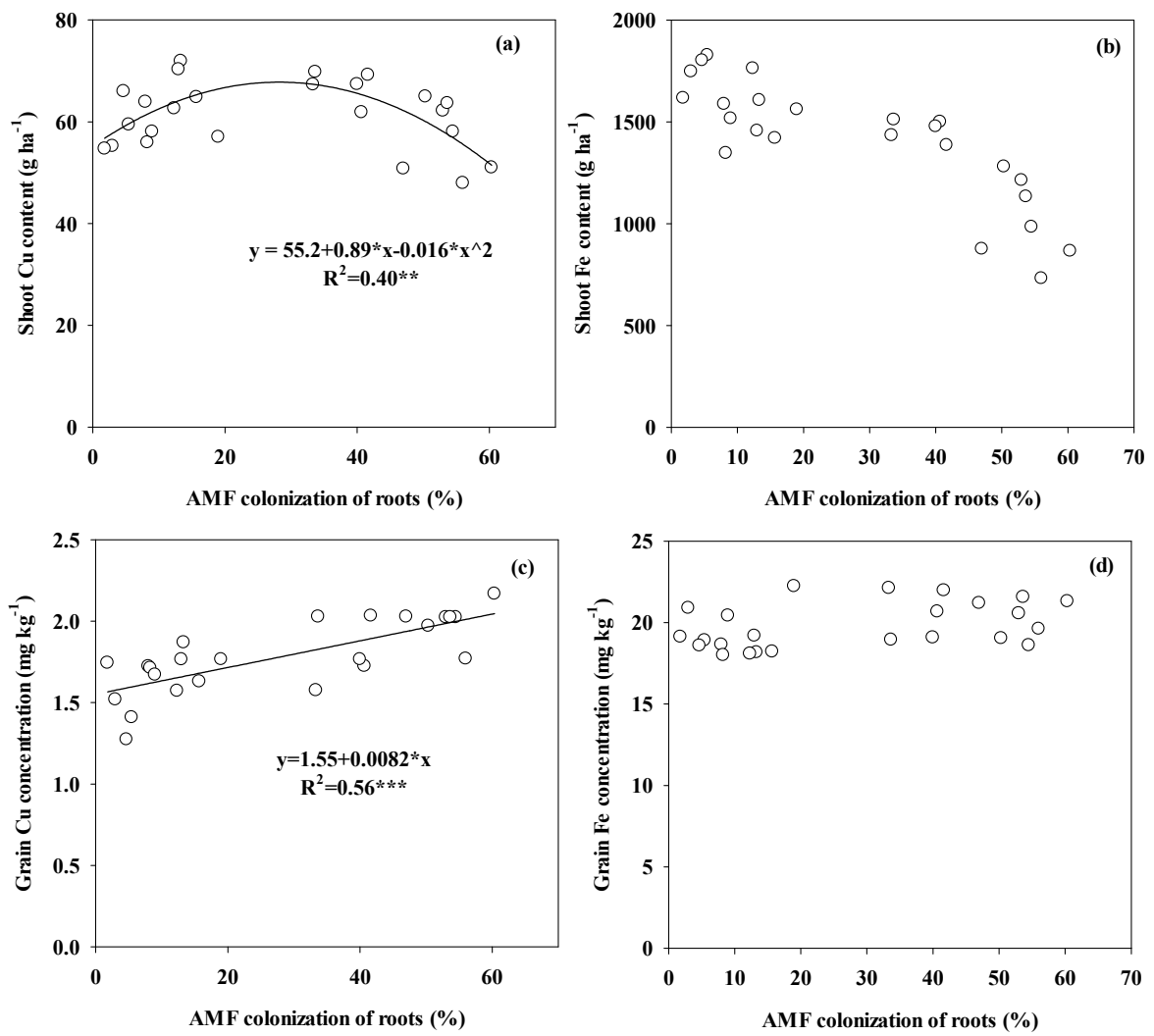

Figure 5. Relationship between AMF colonization of roots and shoot $\mathrm{Cu}$ content (a), shoot Fe content (b), grain Cu concentration (c) and grain Fe concentration (d) at tasseling in 2014 (these data were not collected in 2015). ${ }^{* *}$ and ${ }^{* * *}$ indicates that the regression is significant at $p<0.01$ and $p<0.001$, respectively.

\subsection{Soil Availability of $\mathrm{P}, \mathrm{Cu}$ and Fe Concentrations as Affected by P Fertilization}

Compared to P0, P fertilizer application significantly increased the soil Olsen-P concentration from an average of $9.6 \mathrm{mg} \cdot \mathrm{kg}^{-1}$ under P12.5 to $63.8 \mathrm{mg} \cdot \mathrm{kg}^{-1}$ under the P200 treatment in both years (Figure 6a). Phosphorus fertilizer application had no effect on soil DTPA-Cu (Figure 6b) or DTPA-Fe concentration (Figure 6c) in 2014 and 2015.

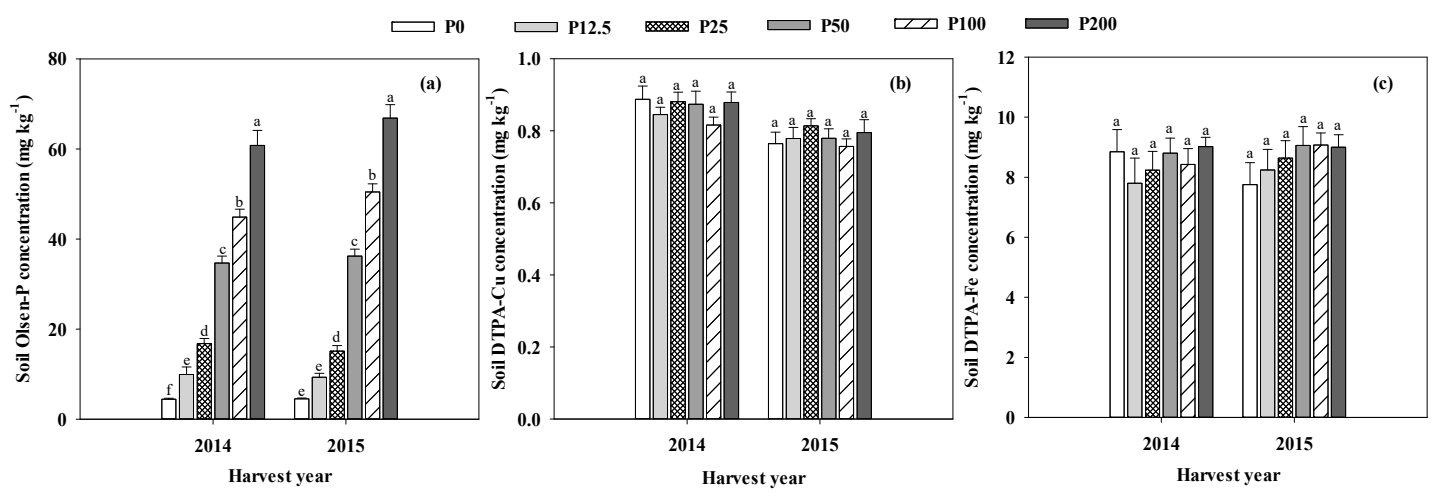

Figure 6. Concentrations of soil Olsen-P (a), DTPA-Cu (b) and DTPA-Fe (c) as affected by P application rate at maturity stage of summer maize. P0, P12.5, P25, P50, P100, and P200 equal 0, 12.5, 25, 50, 100, and $200 \mathrm{~kg} \cdot \mathrm{ha}^{-1} \mathrm{P}$ applied. Values are means $+\mathrm{SE}$ of four replications. Within each year, means with the same letters indicate no significant difference according to an LSD test $(p<0.05)$. 


\section{Discussion}

\subsection{Grain Cu and Fe Nutrition as Affected by P Application and Its Effects for Feed}

In these field experiments, $\mathrm{P}$ application significantly increased maize grain yield, and the $25 \mathrm{~kg} \cdot \mathrm{ha}^{-1} \mathrm{P}$ input was optimal for ensuring grain yield, while excessive input had no benefit on maize yield [13]. Meanwhile, the stover yield of maize was also significantly enhanced with the increasing $\mathrm{P}$ fertilizer rate from 0 to 12.5 (or $25 \mathrm{~kg} \cdot \mathrm{ha}^{-1}$ ), and excessive $\mathrm{P}$ fertilization had no benefit on stover yield [13]. Our findings showed that $\mathrm{P}$ application significantly decreased the grain $\mathrm{Cu}$ concentration by $3.4-23.4 \%$, while an optimal $\mathrm{P}$ application $\left(25 \mathrm{~kg} \cdot \mathrm{ha}^{-1}\right)$ decreased grain $\mathrm{Cu}$ concentration by $8.6 \%$, and excess $\left(200 \mathrm{~kg} \cdot \mathrm{ha}^{-1}\right)$ led to a grain $\mathrm{Cu}$ concentration reduction of $23.4 \%$, whereas $\mathrm{P}$ application had no effect on grain Fe concentration. To our knowledge, this is the first time that a field experiment has reported that grain Fe nutrition is not influenced by $\mathrm{P}$ fertilizer application.

The decreasing $\mathrm{Cu}$ concentration in maize grain may affect the adjustment of feed copper nutrition-if the maize grains produced under higher $\mathrm{P}$ conditions are to be used as fodder and additional $\mathrm{Cu}$ needs to be supplemented. Based on the National Standard of China, the limited contents of $\mathrm{Cu}$ in feeds were $3-6 \mathrm{mg} \cdot \mathrm{kg}^{-1}$ and $8 \mathrm{mg} \cdot \mathrm{kg}^{-1}$ for swine and chicken, respectively [36,37]. However, the current grain $\mathrm{Cu}$ concentration under optimal (25 kg P ha $\left.{ }^{-1}\right)$ and excessive $\left(200 \mathrm{~kg} \mathrm{P} \mathrm{ha}^{-1}\right) \mathrm{P}$ application was only 1.73 and $1.45 \mathrm{mg} \cdot \mathrm{kg}^{-1}$, respectively. The scenario analysis indicated that the current maize grain provided insufficient $\mathrm{Cu}$ for livestock and poultry. It still needs 1.7 to 4.6 times more chemical $\mathrm{Cu}$ addition under optimal $\mathrm{P}$ application to guarantee the feeding $\mathrm{Cu}$ requirement for swine and chicken, and a 2.1- to 5.5-fold increase in $\mathrm{Cu}$ is required under the overuse of $\mathrm{P}$ condition.

Although $\mathrm{P}$ fertilizer did not affect Fe concentrations in grain in the current study, the $\mathrm{Fe}$ bioavailability in grain, which means the Fe homeostasis in the animal intestine, may be largely reduced due to the high phytate concentration with increasing P rates [38,39]. In other words, the conventional manner of overuse of $\mathrm{P}$ fertilizer will severely reduce the Fe intake by the intestinal canal compared to under optimal P application.

In addition, $\mathrm{P}$ fertilization also affected the grain $\mathrm{Zn}$ concentration and content in this study. The grain Zn concentration significantly decreased with the increasing $\mathrm{P}$ fertilizer rate, while the grain Zn content increased first and then decreased [13]. The reasons for the decline in grain Zn concentration could be partly explained by the 'dilution effect' and the rhizosphere effect, such as root length density and AM fungi. P fertilization had no effect on grain manganese concentration, but increased manganese content due to the improvement of grain yield.

\subsection{Does Grain Cu and Fe Nutrition Relate to Uptake or Translocation?}

The copper content in grain and straw increased when low levels of $\mathrm{P}$ were applied to optimal $P$ rates, but they then decreased with high levels of $P$ in the current study. This result was inconsistent with a previous study, which indicated that the $\mathrm{Cu}$ content in rice decreased as the $\mathrm{P}$ application rate increased [40]. This discrepancy might be explained by the effects of P application on plant biomass and $\mathrm{Cu}$ concentration-from the low to the optimal $\mathrm{P}$ application rate, a combined effect with a fast increase in maize biomass and a slight reduction in $\mathrm{Cu}$ concentration resulted in the improvement of $\mathrm{Cu}$ accumulation, while, from optimal to excessive $\mathrm{P}$ application rates, a relatively unchanging shoot biomass and a gradual decline in $\mathrm{Cu}$ concentration led to a reduction in $\mathrm{Cu}$ content. It follows that a reasonable level of $\mathrm{P}$ application in intensive maize production could result in a high level of $\mathrm{Cu}$ content. Previous studies also reported that high levels of $\mathrm{P}$ in the soil had a tendency to reduce the uptake of $\mathrm{Cu}$ by maize roots $[11,41,42]$, while the extent of decline in this study was substantial. Meanwhile, the results further showed that the ratio of grain to shoot $\mathrm{Cu}$ content was not affected by $\mathrm{P}$ application rates. These results therefore indicate that the grain $\mathrm{Cu}$ reduction may be not due to the inhibition of $\mathrm{Cu}$ re-translocation from straw to grain, but instead a synthesis effect of the reduction of root uptake and the potential dilution effect (high yield caused concentration decrease). With regard to the reasons for the ' $\mathrm{P}$ decrease of $\mathrm{Cu}^{\prime}$ ', the 'dilution effect' and the $\mathrm{Cu}$ acquisition capability of 
the root together affect the $\mathrm{Cu}$ concentrations. With a low-available-P soil, increasing the $\mathrm{P}$ fertilizer rapidly enhances crop biomass or yield, and the 'dilution effect' may play an important role in the reduction of $\mathrm{Cu}$ concentration, especially when the amount of $\mathrm{P}$ fertilizer is less increased. On the other hand, with sufficient-available-P soil, increasing the $\mathrm{P}$ fertilizer has little or no effect on the further improvement of crop biomass or yield, but the $\mathrm{Cu}$ concentration is in continuous decline.

The iron content in the current study was increased with $\mathrm{P}$ application rates. The increase in Fe content mainly resulted from an increase in plant biomass rather than an increase in the Fe concentration in maize tissues. In other words, the increase did not result from a direct effect on Fe processing by the plant. The finding that the ratio of grain to shoot Fe content were not affected by $\mathrm{P}$ application indicated that the translocation of Fe from straw to grain was also not affected by $\mathrm{P}$ application, which was consistent with a previous result obtained with wheat [43]. These results indicate that $P$ application might increase Fe uptake, and the re-translocation of Fe from straw to grain was not affected by $\mathrm{P}$ rates.

The reduction in $\mathrm{Cu}$ and $\mathrm{Fe}$ concentration in grain and shoot of maize was also not due to the $\mathrm{Cu}$ and Fe availability in the soil. In fact, the increased $\mathrm{P}$ application did not change the available soil $\mathrm{Cu}$ and Fe in the current study (Figure 6b,c). In a study with wheat, Zhang et al. [43] also indicated that $\mathrm{P}$ application did not affect soil DTPA-Cu concentrations.

\subsection{Cu and Fe Uptake Response to Root Length and AMF Colonization}

Based on the above analysis, the $\mathrm{Cu}$-uptake process by roots was limited under high levels of $\mathrm{P}$. As the rate of $\mathrm{P}$ application increased, the root dry weight and root length density initially increased and then plateaued. The result was inconsistent with previous research, in which a high rate of $P$ application reduced root length density [44]. Haynes and Ludecke [45] have explained the difference made by that large amount of shoot biomass as related to high root biomass to match the grain yield under field conditions. A study by Duncan et al. [46] also indicated that plants which received a co-application of $\mathrm{N}+\mathrm{P}+\mathrm{K}$ fertilizers had an increased overall root length, more root branches and greater root diameters. Another reason for the discrepancy may be that the level of available $\mathrm{P}$ in the soil was lower in the current study than in the study of Schroeder and Janos [44]. Regarding the latter possibility, Wen et al. [19] found that the total maize root length and specific root length decreased when the soil Olsen-P concentration ranged from 54 to $594 \mathrm{mg} \mathrm{g}^{-1}$ in a pot experiment. In the current field experiment, the soil Olsen-P concentration was $<67 \mathrm{mg} \cdot \mathrm{kg}^{-1}$, which may have been too low to restrict root length [47]. Although P application did not reduce root length density, it did reduce specific $\mathrm{Cu}$ uptake. The results indicated that the ability of the roots to absorb $\mathrm{Cu}$ declined as the $\mathrm{P}$ application rate increased [42]. However, this reduction curve of root $\mathrm{Cu}$ uptake could not be explained simply by root length density, from the relationship between root length density and shoot $\mathrm{Cu}$ content (Figure 4a). Previous studies have shown that decreases in the AMF colonization of roots resulted in reduced $\mathrm{Cu}$ concentrations in plants. Li et al. [24] concluded that $\mathrm{Cu}$ uptake and transport by vesicular-arbuscular mycorrhizal hyphae may contribute to the $\mathrm{Cu}$ nutrition of host plants. Our previous results in this study also showed that the AMF colonization of maize roots significantly decreased as the $\mathrm{P}$ application rate increased [13], which was consistent with Liu et al. [48]. Furthermore, AMF colonization, shoot $\mathrm{Cu}$ content and grain $\mathrm{Cu}$ concentration were positively correlated in the current study, which indicated that a decrease in AMF colonization may be a main reason that explains why the $\mathrm{Cu}$ concentrations in grain and straw were reduced by $\mathrm{P}$ application.

The shoot Fe content in this study was improved by P application. Previous studies noted that an increase in root length would increase the plant's capability to obtain mineral nutrients, because it would increase the surface area available for acquiring minerals [49-51]. The current results support this view by indicating that root length density had a positive relationship with shoot Fe content. AMF colonization was unrelated to total Fe content and grain Fe concentration in the current study, which was consistent with Liu et al. [26], who reported that maize absorbed less Fe via the AMF pathway than via the non-mycorrhizal pathway. A meta-analysis also provided evidence that AMF had no effect on Fe nutrition in herb plants [52]. A report had indicated that the photosiderophores produced 
in maize partly sustained Fe acquisition [53]. This means that the photosiderophores production in maize roots was probably not affected by increasing $\mathrm{P}$ application, which needs further study.

\subsection{Phosphorus Management Based on Yield, Grain Cu and Fe Nutrition}

In an intensive maize production system, an appropriate $\mathrm{P}$ fertilizer application is beneficial to realizing higher maize grain yields compared to low $\mathrm{P}$ input [54,55], while excessive $\mathrm{P}$ fertilizer amounts, which exceed the growth requirement, are not advisable. The overuse of $\mathrm{P}$ application will not only lead to sharp declines in grain $\mathrm{Cu}$ concentration under the condition, while the yield will fail to increase compared to appropriate $\mathrm{P}$ application, but it will also cause a further reduced bioavailability of grain $\mathrm{Cu}, \mathrm{Fe}$, and $\mathrm{Zn}[56,57]$. Meanwhile, excessive $\mathrm{P}$ application results in the reduction of AMF colonization [58], and then decreases in P efficiency [59]. From the mechanisms between $\mathrm{P}$ and $\mathrm{Cu}, \mathrm{Fe}$, biological traits and $\mathrm{P}$ management should be synchronously explored to achieve high grain yields and high grain $\mathrm{Cu}$ and Fe contents of maize, and then to reduce the extra $\mathrm{Cu}$ supplementation in industrialized feed production. Importantly, an optimal level of $P$ fertilizer should be established based on soil $\mathrm{P}$ tests and crop requirements to explore the biological potential of crop roots and rhizosphere manipulation.

\section{Conclusions}

Phosphorus application significantly reduced $\mathrm{Cu}$, but not $\mathrm{Fe}$, concentration in grain. Phosphorus application had no effect on $\mathrm{Cu}$ or Fe distribution percentage in grain and straw. The reduction of $\mathrm{Cu}$ concentration could be partly explained by a decrease in the colonization of roots by $\mathrm{AMF}$ due to increasing $\mathrm{P}$ application. If the maize grains produced under the condition of the current $\mathrm{P}$ level (50-200 $\mathrm{kg} \cdot \mathrm{ha}^{-1}$ ) are used as fodder, it will aggravate the $\mathrm{Cu}$ deficiency of livestock. Therefore, an appropriate $\mathrm{P}$ amount in the maize production system is necessary to maintain a higher yield and a suitably high concentration of $\mathrm{Cu}$ for feed.

Author Contributions: Conceptualization, W.Z.; formal analysis, X.C. (Xiuxiu Chen) and Y.L.; funding acquisition, X.C. (Xinping Chen); investigation, X.C. (Xiuxiu Chen), Y.L. and D.L.; methodology, C.Z.; project administration, W.Z.; resources, X.C. (Xiuxiu Chen), Y.L. and D.L.; software, W.Z.; supervision, X.C. (Xinping Chen); validation, W.Z.; visualization, C.Z. and X.C. (Xinping Chen); writing-original draft, W.Z.; writing-review and editing, H.Y. and Y.D. All authors have read and agreed to the published version of the manuscript.

Funding: This research was funded by the National Key R\&D Program of China (NO. 2018YFD0200700), and the National Maize Production System in China (CARS-02-15).

Acknowledgments: Authors sincerely thank the Changiang Scholarship, Ministry of Education, China. This work also was gratefully supported by State Cultivation Base of Eco-agriculture for Southwest Mountainous Land (Southwest University). We thank Bruce Jaffee from the USA for improving the English of the manuscript.

Conflicts of Interest: The authors declare no conflict of interest.

\section{References}

1. Nuss, E.T.; Tanumihardjo, S.A. Quality protein maize for Africa: Closing the protein inadequacy gap in vulnerable populations. Adv. Nutr. 2011, 2, 217-224. [CrossRef] [PubMed]

2. Prasanna, B.M.; Vasal, S.K.; Kassahun, B.; Singh, N.N. Quality protein maize. Encycl. Grain Sci. 2001, 81, 212-216. [CrossRef]

3. Dunn, M.L.; Jain, V.; Klein, B.P. Stability of key micronutrients added to fortified maize flours and corn meal. Ann. N. Y. Acad. Sci. 2014, 1312, 15-25. [CrossRef] [PubMed]

4. Shiferaw, B.; Prasanna, B.M.; Hellin, J.; Bänziger, M. Crops that feed the world 6. Past successes and future challenges to the role played by maize in global food security. Food Secur. 2011, 3, 307-327. [CrossRef]

5. Kaur, J.; Bhatti, S.; Goyal, M. Influence of copper application on forage yield and quality of Oats fodder in copper deficient soils. Indian J. Anim. Nutr. 2015, 32, 290-294.

6. Wysocka, D.; Snarska, A.; Sobiech, P. Copper-an essential micronutrient for calves and adult cattle. J. Elementol. 2019, 24, 101-110. [CrossRef] 
7. Xiong, X.; Li, Y.X.; Li, W.; Lin, C.Y.; H, W.; Yang, M. Copper content in animal manures and potential risk of soil copper pollution with animal manure use in agriculture. Resour. Conserv. Recy. 2010, 54, 985-990. [CrossRef]

8. Debski, B. Supplementation of pigs diet with zinc and copper as alternative to conventional antimicrobials. Pol. J. Vet. Sci. 2016, 19, 917-924. [CrossRef]

9. Banaj, D.; Kovacevic, V.; Simic, D.; Seput, M.; Stojic, B. Phosphorus impacts on yield and nutritional status of maize. Cereal Res. Commun. 2006, 34, 393-396. [CrossRef]

10. Wu, L.; Cui, Z.; Chen, X.; Yue, S.; Sun, Y.; Zhao, R.; Deng, Y.; Zhang, W.; Chen, K. Change in phosphorus requirement with increasing grain yield for Chinese maize production. Field Crops Res. 2015, 180, 216-220. [CrossRef]

11. Wang, H.; Shi, G.; Zhong, G. Effects of phosphorus supply on copper tolerance and ascorbate-glutathione cycle in maize (Zea Mays L.) seedlings. Sens. Lett. 2012, 10, 670-677. [CrossRef]

12. Ova, E.A.; Kutman, U.B.; Ozturk, L.; Cakmak, I. High phosphorus supply reduced zinc concentration of wheat in native soil but not in autoclaved soil or nutrient solution. Plant Soil 2015, 393, 147-162. [CrossRef]

13. Zhang, W.; Chen, X.; Liu, Y.; Liu, D.; Chen, X.; Zou, C. Zinc uptake by roots and accumulation in maize plants as affected by phosphorus application and arbuscular mycorrhizal colonization. Plant Soil 2017, 413, 59-71. [CrossRef]

14. Zhang, W.; Liu, D.; Liu, Y.; Cui, Z.; Chen, X.; Zou, C. Zinc uptake and accumulation in winter wheat relative to changes in root morphology and mycorrhizal colonization following varying phosphorus application on calcareous soil. Field Crops Res. 2016, 197, 74-82. [CrossRef]

15. Ao, J.; Fu, J.; Tian, J.; Yan, X.; Liao, H. Genetic variability for root morph-architecture traits and root growth dynamics as related to phosphorus efficiency in soybean. Funct. Plant Biol. 2010, 37, 304-312. [CrossRef]

16. Gahoonia, T.S.; Nielsen, N.E. Root traits as tools for creating phosphorus efficient crop varieties. Plant Soil 2004, 260, 47-57. [CrossRef]

17. Oikeh, S.O.; Kling, J.G.; Horst, W.J.; Chude, V.O.; Carsky, R.J. Growth and distribution of maize roots under nitrogen fertilization in plinthite soil. Field Crops Res. 1999, 62, 1-13. [CrossRef]

18. Mi, G.; Chen, F.; Yuan, L.; Zhang, F. Ideotype root system architecture for maize to achieve high yield and resource use efficiency in intensive cropping systems. Adv. Agron. 2016, 139, 73-97. [CrossRef]

19. Wen, Z.; Li, H.; Shen, J.; Rengel, Z. Maize responds to low shoot P concentration by altering root morphology rather than increasing root exudation. Plant Soil 2017, 416, 377-389. [CrossRef]

20. Teng, W.; Deng, Y.; Chen, X.; Xu, X.; Chen, R.; Lv, Y.; Zhao, Y.; Zhao, X.; He, X.; Li, B. Characterization of root response to phosphorus supply from morphology to gene analysis in field-grown wheat. J. Exp. Bot. 2013, 64, 1403-1411. [CrossRef]

21. Subramanian, K.S.; Bharathi, C.; Jegan, A. Response of maize to mycorrhizal colonization at varying levels of zinc and phosphorus. Biol. Fert. Soils 2008, 45, 133-144. [CrossRef]

22. Watts-Williams, S.J.; Cavagnaro, T.R. Arbuscular mycorrhizas modify tomato responses to soil zinc and phosphorus addition. Biol. Fert. Soils 2012, 48, 285-294. [CrossRef]

23. Feng, G.; Song, Y.C.; Li, X.L.; Christie, P. Contribution of arbuscular mycorrhizal fungi to utilization of organic sources of phosphorus by red clover in a calcareous soil. Appl. Soil Ecol. 2003, 22, 139-148. [CrossRef]

24. Li, X.L.; Marschner, H.; George, E. Acquisition of phosphorus and copper by VA-mycorrhizal hyphae and root-shoot transport in while clover. Plant Soil 1991, 136, 49-57. [CrossRef]

25. Lambert, D.H.; Baker, D.E.; Cole, H. The role of mycorrhizae in the interactions of phosphorus with zinc, copper, and other elements. Soil Sci. Soc. Am. J. 1979, 43, 976-980. [CrossRef]

26. Liu, A.; Hamel, C.; Hamilton, R.I.; Ma, B.L.; Smith, D.L. Acquisition of Cu, Zn, Mn and Fe by mycorrhizal maize (Zea mays L.) grown in soil at different P and micronutrient levels. Mycorrhiza 2000, 9, 331-336. [CrossRef]

27. Wang, M.; Christie, P.; Xiao, Z.; Qin, C.; Wang, P.; Liu, J.; Xie, Y.; Xia, R. Arbuscular mycorrhizal enhancement of iron concentration by Poncirus trifoliata L. Raf and Citrus reticulata Blanco grown on sand medium under different pH. Biol. Fert. Soils 2009, 45, 65-72. [CrossRef]

28. Deng, Y.; Feng, G.; Chen, X.P.; Zou, C.Q. Arbuscular mycorrhizal fungal colonization is considerable at optimal Olsen-P levels for maximized yields in an intensive wheat-maize cropping system. Field Crops Res. 2017, 209, 1-9. [CrossRef] 
29. Von Wiren, N.; Marschner, H.; Romheld, V. Uptake kinetics of iron-phytosiderophores in two maize genotypes differing in iron efficiency. Physiol. Plantarum 1995, 93, 611-616. [CrossRef]

30. Curie, C.; Panaviene, Z.; Loulergue, C.; Dellaporta, S.L.; Briat, J.; Walker, E.L. Maize yellow stripe1 encodes a membrane protein directly involved in Fe (III) uptake. Nature 2001, 409, 346-349. [CrossRef]

31. Jolley, V.D.; Cook, K.A.; Hansen, N.C.; Stevens, W.B. Plant physiological responses for genotypic evaluation of iron efficiency in strategy I and strategy II plants-A review. J. Plant Nutr. 1996, 8-9, 1241-1255. [CrossRef]

32. Oburger, E.; Gruber, B.; Schindlegger, Y.; Schenkeveld, W.D.; Hann, S.; Kraemer, S.M.; Wenzel, W.W.; Puschenreiter, M. Root exudation of phytosiderophores from soil-grown wheat. New Phytol. 2014, 203, 1161-1174. [CrossRef]

33. Ptashnyk, M.; Roose, T.; Jones, D.L.; Kirk, G.J. Enhanced zinc uptake by rice through phytosiderophore secretion: A modelling study. Plant Cell Environ. 2011, 34, 2038-2046. [CrossRef]

34. Olsen, S.R. Estimation of Available Phosphorus in Soils by Extraction with Sodium Bicarbonate; Miscellaneous Paper Institute for Agricultural Research Samaru; US Department of Agriculture: Washington DC, USA, 1954.

35. Lindsay, W.L.; Norvell, W.A. Development of a DTPA soil test for zinc, iron, manganese, and copper. Soil Sci. Soc. Am. J. 1978, 42, 421-428. [CrossRef]

36. Li, D.F.; Wang, K.N.; Qiao, S.Y.; Jia, G.; Jiang, Z.Y.; Chen, Z.L.; Lin, Y.C.; Wu, D.; Zhu, X.M.; Xiong, B.H.; et al. NY/T65-2004 Feeding Standard of Swine; Ministry of Agriculture of the People's Republic of China: Beijing, China, 2004. (In Chinese)

37. Wen, J.; Cai, H.Y.; Guo, Y.M.; Qi, G.H.; Chen, J.L.; Zhang, G.Z.; Liu, G.H.; Xiong, B.H.; Su, J.S.; Ji, C.; et al. NY/T 33-2004 Feeding Standard of Chicken; Ministry of Agriculture of the People's Republic of China: Beijing, China, 2004. (In Chinese)

38. Gibson, R.S.; Bailey, K.B.; Gibbs, M.; Ferguson, E.L. A review of phytate, iron, zinc, and calcium concentrations in plant-based complementary foods used in low-income countries and implications for bioavailability. Food Nutr. Bull. 2010, 31, S134-S146. [CrossRef]

39. Raboy, V. Seeds for a better future: 'low phytate' grains help to overcome malnutrition and reduce pollution. Trends Plant Sci. 2001, 6, 458-462. [CrossRef]

40. Haldar, M.; Mandal, L.N. Effect of phosphorus and zinc on the growth and phosphorus, zinc, copper, iron and manganese nutrition of rice. Plant Soil 1981, 59, 415-425. [CrossRef]

41. Baldi, E.; Miotto, A.; Ceretta, C.A.; Quartieri, M.; Sorrenti, G.; Brunetto, G.; Toselli, M. Soil-applied phosphorous is an effective tool to mitigate the toxicity of copper excess on grapevine grown in rhizobox. Sci. Hortic-Amst. 2018, 227, 102-111. [CrossRef]

42. Awan, Z.I.; Abbasi, M.K. Interactive effect of phosphorus and copper on maize growth. Pak. J. Agric. Res. 2000, 16, 105-108.

43. Zhang, Y.; Deng, Y.; Chen, R.; Cui, Z.; Chen, X.; Yost, R.; Zhang, F.; Zou, C. The reduction in zinc concentration of wheat grain upon increased phosphorus-fertilization and its mitigation by foliar zinc application. Plant Soil 2012, 361, 143-152. [CrossRef]

44. Schroeder, M.S.; Janos, D.P. Plant growth, phosphorus nutrition, and root morphological responses to arbuscular mycorrhizas, phosphorus fertilization, and intraspecific density. Mycorrhiza 2005, 15, $203-216$. [CrossRef]

45. Haynes, R.J.; Ludecke, T.E. Yield, root morphology and chemical composition of two pasture legumes as affected by lime and phosphorus applications to an acid soil. Plant Soil 1981, 62, 241-254. [CrossRef]

46. Duncan, E.G.; O'Sullivan, C.A.; Roper, M.M.; Palta, J.; Whisson, K.; Peoples, M.B. Yield and nitrogen use efficiency of wheat increased with root length and biomass due to nitrogen, phosphorus, and potassium interactions. J. Plant Nutr. Soil Sc. 2018, 181, 364-373. [CrossRef]

47. Huang, C.; Webb, M.J.; Graham, R.D. Pot size affects expression of Mn efficiency in barley. Plant Soil 1996, 178, 205-208. [CrossRef]

48. Liu, W.; Zhang, Y.; Jiang, S.; Deng, Y.; Christie, P.; Murray, P.J.; Li, X.; Zhang, J. Arbuscular mycorrhizal fungi in soil and roots respond differently to phosphorus inputs in an intensively managed calcareous agricultural soil. Sci. Rep. UK 2016, 6, 24902. [CrossRef] [PubMed]

49. White, P.J.; George, T.S.; Dupuy, L.X.; Karley, A.J.; Valentine, T.A.; Wiesel, L.; Wishart, J. Root traits for infertile soils. Front. Plant Sci. 2013, 4, 193-199. [CrossRef] 
50. Waddell, H.A.; Simpson, R.J.; Ryan, M.H.; Lambers, H.; Garden, D.L.; Richardson, A.E. Root morphology and its contribution to a large root system for phosphorus uptake by Rytidosperma species (wallaby grass). Plant Soil 2017, 412, 7-19. [CrossRef]

51. Clark, R.B. Differences among mycorrhizal fungi for mineral uptake per root length of switchgrass grown in acidic soil. J. Plant Nutr. 2002, 25, 1753-1772. [CrossRef]

52. Lehmann, A.; Rillig, M.C. Arbuscular mycorrhizal contribution to copper, manganese and iron nutrient concentrations in crops-A meta-analysis. Soil Biol. Biochem. 2015, 81, 147-158. [CrossRef]

53. Masalha, J.; Kosegarten, H.; Elmaci, Ö.; Mengel, K. The central role of microbial activity for iron acquisition in maize and sunflower. Biol. Fert. Soils 2000, 30, 433-439. [CrossRef]

54. MacDonald, G.K.; Bennett, E.M.; Potter, P.A.; Ramankutty, N. Agronomic phosphorus imbalances across the world's croplands. Proc. Natl. Acad. Sci. USA 2011, 108, 3086-3091. [CrossRef]

55. Roberts, T.L.; Johnston, A.E. Phosphorus use efficiency and management in agriculture. Resour. Conserv. Recy. 2015, 105, 275-281. [CrossRef]

56. Lazarte, C.E.; Carlsson, N.; Almgren, A.; Sandberg, A.; Granfeldt, Y. Phytate, zinc, iron and calcium content of common Bolivian food, and implications for mineral bioavailability. J. Food Compos. Anal. 2015, 39, 111-119. [CrossRef]

57. Zhang, W.; Liu, D.; Liu, Y.; Chen, X.; Zou, C. Overuse of phosphorus fertilizer reduces the grain and flour protein contents and zinc bioavailability of winter wheat (Triticum aestivum L.). J. Agr. Food Chem. 2017, 65, 1473-1482. [CrossRef]

58. Lambers, H.; Martinoia, E.; Renton, M. Plant adaptations to severely phosphorus-impoverished soils. Curr. Opin. Plant Biol. 2015, 25, 23-31. [CrossRef]

59. Seguel, A.; Barea, J.M.; Cornejo, P.; Borie, F. Role of arbuscular mycorrhizal symbiosis in phosphorus-uptake efficiency and aluminium tolerance in barley growing in acid soils. Crop Pasture Sci. 2015, 66, 696-705. [CrossRef]

Publisher's Note: MDPI stays neutral with regard to jurisdictional claims in published maps and institutional affiliations.

(C) 2020 by the authors. Licensee MDPI, Basel, Switzerland. This article is an open access article distributed under the terms and conditions of the Creative Commons Attribution (CC BY) license (http://creativecommons.org/licenses/by/4.0/). 